\title{
Maturational regression of glomeruli determines the nephron population in normal mice
}

Jianyong Zhong, Daniel Scott Perrien, Hai-Chun Yang, Valentina Kon, Agnes B. Fogo, lekuni Ichikawa and Ji Ma

Pedatr Res 72:241-248 (2012); doi:10.1038/pr.2012.81

Following publication of this paper, the authors found that an acknowledgment had been omitted. The following sentence should have appeared at the end of the Statement of Financial Support section:

"The work involving use of Scanco microCT was supported by the Vanderbilt University Institute of Imaging Sciences and National Institutes of Health grant S10RR027631."

The authors regret the error.

\section{Pharmacokinetics and safety of a single intravenous dose of myo-inositol in preterm infants of 23-29 wk}

Dale L. Phelps, Robert M. Ward, Rick L. Williams, Kristi L. Watterberg, Abbot R. Laptook, Lisa A. Wrage, Tracy L. Nolen, Timothy R. Fennell, Richard A. Ehrenkranz, Brenda B. Poindexter, C. Michael Cotten, Mikko K. Hallman, Ivan D. Frantz III, Roger G. Faix, Kristin M. Zaterka-Baxter, Abhik Das, M. Bethany Ball, T. Michael O'Shea, Conra Backstrom Lacy, Michele C. Walsh, Seetha Shankaran, Pablo J. Sánchez, Edward F. Bell and Rosemary D. Higgins ; for the Eunice Kennedy Shriver National Institute of Child Health and Human Development Neonatal Research Network

Pediatr Res 74:721-729 (2013); doi:10.1038/pr.2013.162

As the result of an editing error, the following paragraph was omitted from the Disclosure section of the article. The following should have appeared at the end of the section. The publisher regrets the error.

The NICHD Pediatric Pharmacology Research Unit network provided support and advice in designing the PK study (J.V.A., J.v.d.A., A.A.V., S.E.K.), analyzing the data (S.E.K.), and conducting the inositol assay (R.D.L.): Jacob V. Aranda, MD, PhD, FRCPC, Wayne State University (U10 HD37261); John van der Anker, MD, Children's National Medical Center (U10 HD45993); Steven E. Kern, $\mathrm{PhD}$, College of Pharmacy, University of Utah Medical Center; Alexander A. Vinks, PharmD, PhD, FCP, Cincinnati Children's Hospital Medical Center, Department of Pediatrics, University of Cincinnati (U10 HD37249); and Richard D. Leff, PharmD, FCCP, Texas Tech University Health Sciences Center, Pediatric Pharmacology Research and Development Center (U10 HD46000). 